\title{
Relationship Between the Presence of Agger Nasi Cells and the Development of Frontal Sinusitis: a Computer-Assisted Anatomic Study
}

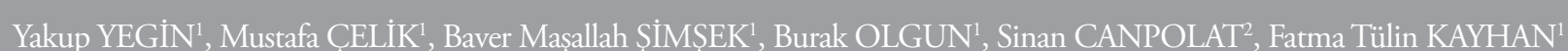

'Clinic of Ear, Nose and Throat Head and Neck Surgery, Bakırköy Dr. Sadi Konuk Training ve Research Hospital, İstanbul, Turkey

${ }^{2}$ Clinic of Ear, Nose and Throat Head and Neck Surgery, Siirt State Hospital, Siirt, Turkey

\section{ABSTRACT}

Objective: To use computed tomography (CT) to determine the relationship between agger nasi (AN) cells and the development of frontal sinusitis.

Methods: In total, 996 patients (402 females and 594 males; average age, 37.2 \pm 12.8 years; range, 18-75 years) underwent a CT scan due to frontal sinusitis. The presence of AN cells was recorded. Patients were divided two groups according to the presence of the AN cell. The Lund- Mackay score (LMS) of each paranasal sinus shadow was evaluated in all patients. The LMS in the groups were compared. A p-value of $<0.05$ was considered to reflect statistical significance.

Results: In the right side, the average LMS of patients with AN cells was 3.5 \pm 2.6 and was $2.3 \pm 2.1$ for those without AN cells. The LMS of patients with AN cells was significantly better than that for those without $\mathrm{AN}$ cells for the right side $(\mathrm{p}<0.05)$. In the left side, the average LMS of patients with AN cells was $3.7 \pm 2.9$ and was $21 \pm 2.2$ for those without AN cells. The LMS of patients with AN cells was significantly better than that for those without AN cells for the left side $(\mathrm{p}<0.05)$.

Conclusion: In the present study, the presence of AN cells may be associated with the development of frontal sinusitis. Further studies with a higher number of patients are needed to explore the relationship between the pneumatization of AN cells and the development of frontal sinusitis.

Keywords: Agger nasi cells, frontal sinusitis, frontal recess

\section{Introduction}

Chronic sinusitis is a disease frequently encountered in recent years that negatively affects the quality of life of patients. The pathophysiology of sinusitis is explained by impaired sinus ventilation through the sinus ostium, and the factors affecting the sinus ostium size play a role in frontal sinusitis development (1). The cells around the frontal recess and their inflammation cause sinus ostium narrowing and impair sinus ventilation, and this is suggested to cause the frontal sinusitis development (2). However, the relationship between the frontal recess cells and frontal sinusitis development is still unclear.

In 1901, Hirschmann introduced endoscopic sinus surgery with the very first examination of the middle meatus in the nasal cavity through a cystoscope (3). It was further developed with the contribution of researchers such as Draf, Grunberg, Messerklinger, Bauer, and Wodak (4). The developments in the endoscopic sinus surgery have increased the significance of detailed anatomy and variations of the paranasal sinuses. In addition, further research is required for additional information on the frontal recess.

Cite this article as: Yegin Y, Çelik M, Şimşek BM, Olgun B, Canpolat S, Kayhan FT. Relationship Between the Presence of Agger Nasi Cells and the Development of Frontal Sinusitis: a Computer-Assisted Anatomic Study. Bezmialem Science 2017; 5 : 112-5.

Address for Correspondence: Mustafa ÇELiK; Bakırköy Dr. Sadi Konuk Eğitim ve Araştırma Hastanesi, İstanbul, Türkiye Received : 31.05 .2016 E-mail:dr.mcelik@yahoo.com

oCopyright 2017 by Bezmialem Vakif University - Available online at www.bezmialemscience.org

Accepted $\quad: 18.07 .2016$ 
The frontal recess is a three-dimensional formation that provides a relation between the frontal sinus and nasal cavity. The structures around it affect the frontal recess and frontal sinus anatomy. Agger nasi (AN) cells are the frontal ethmoidal cells localized in front of the anterior end of the middle turbinate and uncinate process in the nasal lateral wall. The existence of these cells and the degree of pneumatization affect the anteroposterior diameter of the frontal sinus ostium, size of the frontal bone, and drainage pattern of the frontal sinus $(5,6)$.

To reduce the endoscopic sinus surgery complications and surgically correct the anatomic variations that are considered to cause chronic sinusitis and breaking the cycle, an understanding of the variations is required.

The ideal way to avoid the sinus surgery complications is to have a thorough knowledge of the paranasal sinus anatomy (3). The most beneficial method to achieve this is radiological examination. Computed tomography (CT) is the ideal imaging technique for evaluating inflammatory sinus diseases and osteomeatal complex. The CT scan provides detailed preoperative anatomic information, which can act as a surgical map during operation for surgeons. Therefore, a preoperative evaluation of anatomy and variations through CT is essential for protection against complications (7).

In this study, CT images of the patients with chronic frontal sinusitis that were followed up in our clinic were evaluated according to the Lund-Mackay system (LMS) (8), and the presence of the AN cells in coronal CT sections was examined. The relationship between the frontal sinusitis and presence of the AN cells was assessed.

\section{Methods}

This retrospective study was conducted on 996 patients aged $\geq 18$ years who had been admitted between January 2011 and January 2015 to the Clinic of Otolaryngology, Head and Neck Surgery for the sinusitis symptoms such as nasal obstruction, nasal discharge, headache, and facial pain. The patients had undergone paranasal sinus CT scan for etiological investigation as no improvements in their complaints were observed with medical treatment, and the CT scan revealed mucosal thickening in the frontal sinuses. The patients who were $<18$ years old, who had previously undergone any surgical procedure for the paranasal sinus, who had massive nasal polyposis, nasal cavity, and paranasal sinus neoplasm, and who had a history of maxillofacial trauma were excluded from the study. Complete otorhinolaryngological and endoscopic nasal examinations were performed in all the patients. They were medically followed up due to sinusitis in our clinic for a minimum of 6 months. The CT scan was performed for all the patients whose complaints did not improve despite the 6-month medical follow-up. All paranasal sinus CT scans were evaluated according to the LMS. In the CT scan, frontal sinusitis was radiologically accepted to be of a minimum of $3 \mathrm{~mm}$ thickness in sinus ostium or the nasal lateral walls. Surgical intervention was recommended for patients having pathologies such as septum deviation, large concha bullosa, and retention cyst in the scan, and an appropriate surgical procedure was performed accordingly. All patients were informed about the study, and their written informed consents were obtained. The study was approved by the ethical committee of the same hospital (ethical committee approval no: 2016/38). Demographic data of the patients were obtained by scanning the patient files in the hospital's recording system. For CT evaluations, multidetector CT device (Siemens Sensation 40, Erlangen, Germany) was used. The images captured at the radiation dose of 120 $\mathrm{kV}-220 \mathrm{~mA}$, with a minimum of $150-400$ sections and $0.5 \mathrm{~mm}$ thickness, and with a screening area of $21.8 \times 28.8$ $\mathrm{cm}$ were evaluated. The images were obtained without providing contrast media and in bone algorithm. Coronal and sagittal CT sections were used for examination. The images were assessed using the Mediplus Dicom Viewer ${ }^{\circ}$ system (Mediplus Ltd., High Wycombe, UK). The CT examination was performed with the patient in prone position with the head in hyperextension. The AN cells were defined as the anterior ethmoidal cells pneumatized from the frontal recess, as previously defined by Messerklinger (4). The presence of these cells was recorded. The right and left sides were evaluated separately. The patients were categorized into two groups according to the presence of the AN cell. All measurements were evaluated by the same researcher, and they were repeated by another researcher to minimize the error margin.

\section{Statistical Analysis}

Statistical analysis was performed using the Number Cruncher Statistical System 2007 software (Kaysville, Utah, USA). In addition to descriptive statistics (mean, standard deviation, median, frequency, and rate), the KolmogorovSmirnov test was also performed to determine the distribution of variables, and the Mann-Whitney $U$ test was performed to evaluate the two groups. The results were evaluated within $95 \%$ confidence interval and with a significance level of $p<0.05$.

\section{Results}

The study included a total of 996 patients, of whom 402 were females (40.3\%) and 594 were males (59.7\%). Their age ranged between 18 and 75 years, and the mean age was $37.2 \pm 12.8$ years. In the evaluation of the right side, the AN cells were observed in 584 patients (58.6\%) and were not observed in the remaining 412 patients (41.4\%), and the mean LMS score was 3.5 \pm 2.6 in the group with the cells and $2.3 \pm 2.1$ in the group without the cells. This score was significantly higher in the group with the AN cell than that in the other group ( $p=0.0018$ ) (Picture 1a). On the other hand, in the evaluation of the left side, the AN cells were observed in 

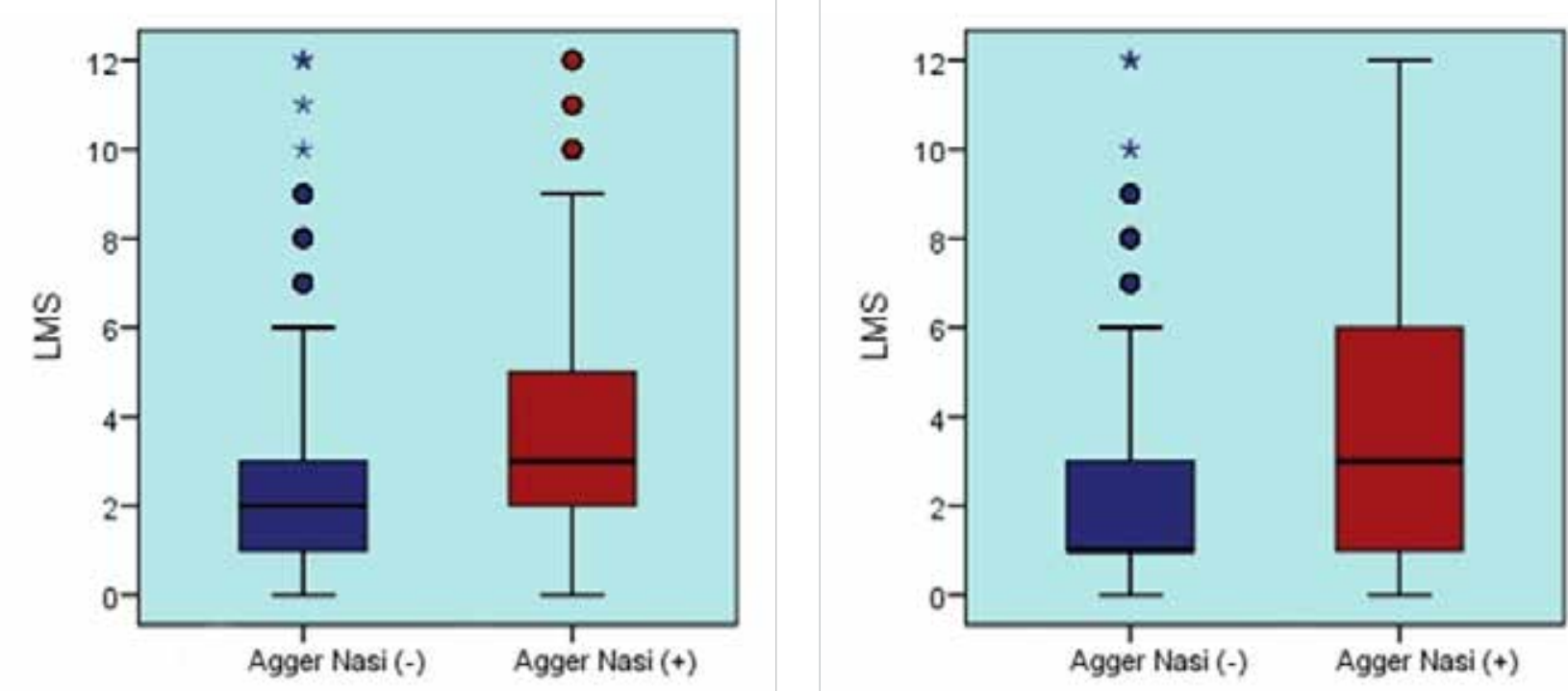

Picture 1. a, b. Correlation between the presence of AN cell and LMS in the right (1a) and left (1b) sides. (AN: agger nasi cell; LMS: Lund-Mackay Scoring)

\section{Table 1. General features of the patients}

\begin{tabular}{l|c} 
Feature & Mean (\%) \\
\hline $\begin{array}{l}\text { Age } \\
\text { Gender }\end{array}$ & $37.2 \pm 12.8$ years (18-75 years) \\
$\quad$ Female & $402(40.3 \%)$ \\
$\quad$ Male & $594(59.7 \%)$ \\
Right side & \\
->Agger nasi(+) & $584(58.6 \%)$ \\
->Agger nasi(-) & $412(41.4 \%)$ \\
Left side & \\
->Agger nasi(+) & $543(54.5 \%)$ \\
->Agger nasi(-) & $453(45.5 \%)$
\end{tabular}

Table 2. The relationship between the agger nasi cell and Lund-Mackay scoring

\begin{tabular}{|c|c|c|c|}
\hline & & 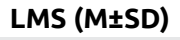 & P* \\
\hline \multirow[t]{2}{*}{ RIGHT } & $\mathrm{AN}(+)$ & $3.5 \pm 2.6$ & 0.0001 \\
\hline & $\mathrm{AN}(-)$ & $2.3 \pm 2.1$ & \\
\hline \multirow[t]{2}{*}{ LEFT } & $\mathrm{AN}(+)$ & $3.7 \pm 2.9$ & 0.0001 \\
\hline & $\mathrm{AN}(-)$ & $2.1 \pm 2.2$ & \\
\hline \multicolumn{4}{|c|}{ AN: agger nasi cell; LMS: Lund-Mackay scoring } \\
\hline
\end{tabular}

543 patients $(54.5 \%)$ and were not observed in the remaining 453 patients (45.5\%) (Table 1). Additionally, the mean LMS score was 3.7 \pm 2.9 in the group with the cells and $2.1 \pm 2.2$ in the group without the cells. This score was significantly higher in the group with the AN cell than that in the other group $(p=0.0039)$ (Picture 1b). Regardless of the sides, the mean the group with the AN cells than that in the group without the cells $(\mathrm{p}<0.05)($ Table 2$)$.

\section{Discussion}

Frontal sinus is one of the several regions that can be treated endoscopically $(1,2)$. Owing to the anatomic structure (the region with essential anatomic formations) and its knowledge and various structural variations, the decision to perform an endoscopic surgery is not rational (5). To understand the frontal recess anatomy, the simplest structures should be considered first as it is difficult to understand complex structures before simple understanding the anatomic structures. In the simplest case, the patient can have only one AN cell without the frontal ethmoidal cells.

The borders of the frontal recess are the lamina paprisea in the lateral, middle concha in the medial, superior wall of AN cells (if present) in the anterior, and posteroanterior wall, including the ethmoid in the posterior (9). In adults, the depth, width, and borders of the frontal recess depend on the anterior ethmoidal cells and embryological pneumatization pattern of the neighboring bone structures $(5,9)$. The AN cells can narrow down the frontal recess and negatively affect the pneumatization of the anterior middle meatus (9). Because of this narrowing, its presence can also cause frontal sinus discharge pathologies and can complicate the endoscopic intervention to the frontal recess, and thus to the sinus. While there are many studies on the frequency of frontal cells, the number of studies revealing the relationship between frontal cells (including AN cells) and frontal sinusitis is limited.

In the study by Meyer et al. (10), while a significant relationship was reported between Type 3 and Type 4 frontal cells and frontal sinusitis, no significant relationship of these with 
other cells is reported. DelGaudio et al. (11) and Eweiss et al. (12) observed no relationship between the presence of AN cells or frontal cells and frontal sinusitis. Similarly, in the study by Kubota et al. (13) on 150 Japanese patients, the presence of AN cells was stated to be an ineffective factor in frontal sinusitis development. The authors also specified that there was no significant relationship between other frontal cells and the frontal sinusitis development. In our study, the effect of the AN cells on the frontal sinusitis development was investigated in the evaluation of right and left sides of the patients. In this evaluation, LMS was found to be significantly higher in the side with the AN cells. Unlike the other studies available, we revealed the effect of the presence of the AN cells on the frontal sinusitis development. This probably resulted from the difference in the AN cell definitions. The different frequency rates of the AN cells that was found in two frequency studies conducted in the same community are also presumably because of the differences in the definitions. In this study, the AN cells were defined as the anterior ethmoidal cell pneumatized from the frontal recess, as previously defined by Messerklinger (4).

The limitations of our study are as follows: Other frontal cells that could affect frontal sinusitis development could not be evaluated in our study. Because it was a retrospective study, the factors such as allergy, smoking, and systemic disease, which could affect the sinusitis development, were also considered. Moreover, if we had evaluated pneumatization and the presence of the AN cells, this study could have been more valuable. Further prospective radiological studies evaluating all frontal cells on a larger population are required.

\section{Conclusion}

In this study, the LMS score was higher in the group with the AN cells. Further studies on s larger number of patients should be conducted to investigate the effect of the AN cell volume on the sinusitis development and the presence of the AN cell.

Ethics Committee Approval: Ethics committee approval was received for this study from the ethic committee of Bakırköy Dr. Sadi Konuk Training and Research Hospital.

Informed Consent: Written informed consent was obtained from each participant.

Peer-review: Externally peer-reviewed.

Author Contributions: Concept - Y.Y, M.Ç, B.M.Ş, B.O., S.C., F.T.K.; Design - Y.Y, M.Ç, B.M.Ş, B.O., S.C., F.T.K.; Supervi- sion - Y.Y, M.Ç, B.M.Ş, B.O., S.C., F.T.K.; Data Collection and/ or Processing -Y.Y, M.Ç, B.M.Ş, B.O., S.C., F.T.K.; Analysis and/ or Interpretation- Y.Y, M.Ç, B.M.Ş, B.O., S.C., F.T.K.; Literature Review - Y.Y, M.Ç, B.M.Ş, B.O., S.C., F.T.K.; Writing - Y.Y, M.Ç, B.M.Ş, B.O., S.C., F.T.K.; Critical Review - Y.Y, M.Ç, B.M.Ş, B.O., S.C., F.T.K.

Conflict of Interest: No conflict of interest was declared by the authors.

Financial Disclosure: The authors declared that this study has received no financial support.

\section{References}

1. Azila A, Irfan M, Rohaizan Y, Shamim AK. The prevalence of anatomical variations in osteomeatal unit in patients with chronic rhinosinusitis. Med J Malaysia 2011; 66: 191-4.

2. Lee WT, Kuhn FA, Citardi MJ. 3D computed tomographic analysis of frontal recess anatomy in patients without frontal sinusitis. Otolaryngol Head Neck Surg 2004; 131: 164-73. [CrossRef]

3. Kennedy DW, Zinreich SJ, Kuhn F, Shaalan H, Naclerio R, Loch E.Endoscopic middle meatal antrostomy:theory,technique and patency. Laryngoscope 1987; 97: 1-9. [CrossRef]

4. Messerklinger W. Endoscopy of the nose. Baltimore: Urban and Schwaaenberg, 1978.

5. Wormald PJ. The agger nasi cell: the key to understanding the anatomy of the frontal recess. Otolaryngol Head Neck Surg 2003; 129: 497-507. [CrossRef]

6. Orhan İ, Soylu E, Altın G, Yılmaz F, Çalım ÖF, Örmeci T.Paranazal Sinüs Anatomik Varyasyonlarının Bilgisayarlı Tomografi ile Analizi.Abant Med J 2014; 3: 145-9. [CrossRef]

7. Pata YS, Ünal M, Akbaş Y. Paranazal sinüsler ve nazal kavitenin anatomik varyasyonları;bilgisayarlı tomografi çalışması.Türk Otolarengoloji Arşivi 2005; 43: 201-6.

8. Lund VJ, Mackay IS. Staging in rhinosinusitis. Rhinology 1993; 31: 183-4.

9. Jacobs JB, Lebowitz RA, Sorin A, Hariri S, Holliday R. Preoperative sagittal CT evaluation of the frontal recess. Am J Rhinol 2000; 14: 33-7. [CrossRef]

10. Meyer TK, Mehmet K, Smith MM, Smith TL. Coronal computed tomography analysis of frontal cells. Am J Rinol 2003; 17: 163-8.

11. DelGaudio JM, Hudgins PA, Venkatraman G, Beningfield A. Multiplanar computed tomographic analysis of frontal recess cells. Arch Otolaryngol Head Neck Surg 2005; 131: 230-5. [CrossRef]

12. Eweiss AZ, Khalil HS. The prevalence of frontal cells and their relation to frontal sinusitis: a radiological study of the frontal recess area. ISRN Otolaryngol 2013; 2013: 687582.

13. Kubota K, Takeno S, Hirakawa K. Frontal recess anatomy in Japanese subjects and its effect on the development of frontal sinusitis: computed tomography analysis. J Otolaryngol Head Neck Surg 2015; 44: 21. [CrossRef] 